\title{
ENTREVISTA COM STEVE MCCURRY (BILÍNGUE)
}

\section{INTERVIEW WITH STEVE MCCURRY (BILINGUAL)}

MARIA DO CARMO NINO - Como você considera e resolve na prática os campos entre fotografia / arte / documento enquanto tensões inseridas no contexto do seu trabalho?

MARIA DO CARMO NINO - How do you deal and solve on your practice the fields among photography / art / document while tensions within the context of your work?

SM - The lines that once made for distinct categories have blurred substantially. Documentary photography has become more and more accepted in the fine art market. People respond to these photographs because there is a universal chord that speaks to people.

SM - As linhas que antes foram feitas para distinguir categorias turvaram-se substancialmente. Fotografia documental tornou-se cada vez mais aceita no mercado de arte. As pessoas respondem a essas fotos porque existe um acorde universal que fala para as pessoas.

EDUARDO QUEIROGA - Na fotografia documental, o assunto fotografado é muito importante, não podemos negligenciá-lo. Como acontece a articulação entre a assinatura do fotógrafo (a expressão de sua subjetividade) e o respeito ao assunto, ao tema documentado?

EDUARDO QUEIROGA - In documentary photography, the photographic subject is very important, we cannot neglect it. How is the articulation between the signature of the photographer (expressing his subjectivity) and the respect to the subject, to the issue documented?

SM - My goal is to make an image that is representative, true and honest to what or who is in front of the lens. That trumps any stylistic intent. I photograph what catches 
my eye, so you could say that my style has more to do with the way I observe. In the back of my mind I'm aware of seeking a look that helps capture the truth of a situation or the essence of a person, a glimpse of their humanity.

SM - Meu objetivo é fazer uma imagem que seja representativa, verdadeira e honesta para o que ou quem está na frente da lente. Isso supera qualquer intenção estilística. Eu fotografo o que me chama a atenção, assim você poderia dizer que meu estilo tem mais a ver com a maneira que eu observo. No fundo da minha mente estou ciente de buscar um olhar que ajude a capturar a verdade de uma situação ou a essência de uma pessoa, um vislumbre de sua humanidade.

FERNANDO DE MENDONÇA - A pessoa que olha para uma fotografia da série Portraits experimenta o reflexo de seu gesto por também se sentir olhada pela imagem. Torna-se uma espécie de espelho que tanto revela a sua autoconsciência de fotógrafo (não deixam de serem imagens autobiográficas) como a subjetividade do olhar espectador. Num dos fragmentos de Rousseau (Meu Retrato, 1760), temos que "os traços de um rosto só produzem seus efeitos porque nele estão todos juntos; a falta de um desfigura todo o rosto". Considerando esta totalidade própria do retrato e a relação da imagem para com aquele que a observa, como você compreende esta via de mão dupla? Está claro que o seu tratamento na individualidade de quem posa visa um confronto com o self de quem contemplará suas fotografias, mas é possível pensar em um restabelecimento existencial como resultado desta experiência?

FERNANDO DE MENDONÇA - The person who looks at a photograph of the series Portraits experiences the reflection of his/her gesture by also feeling like looked by the picture. It becomes a kind of mirror that reveals both your self-conscience of photographer (they are nonetheless autobiographical images) as the subjectivity of the viewer look. In one of the fragments of Rousseau (My Portrait, 1760), we have that "traces of a face only produce their effects because in the face they are all together; the lack of one trace disfigures the whole face". Considering this own totality of the portrait and the relationship of the image to the one who looks at it, how do you understand this two-way street? It's clear that your treatment in individuality of whom poses seeks a confrontation with the self of whom will contemplate your photos, but it's possible to think of an existential restoration as a result of this experience?

SM - I want people to think about the content of my portraits. I'm fascinated by how different we all look, and by how much you can see just by looking at the face. It's like peering down a well, and there it is reflecting back at you. A good portrait is one that says something about the person. We always sort of see ourselves in other people, so a good portrait also says something about the human condition. We see emotions in that person that we can relate to - happiness, sadness, suffering. 
SM - Eu quero que as pessoas pensem sobre o conteúdo dos meus retratos. Sou fascinado por quão diferente todos nós olhamos, e por quanto você pode ver apenas olhando para o rosto. É como se olhássemos para o fundo de um poço, e lá reflete de volta para você. Um bom retrato é aquele que diz algo sobre a pessoa. Nós sempre de uma certa maneira vemos nós mesmos em outras pessoas, então um bom retrato também diz algo sobre a condição humana. Vemos emoções naquela pessoa que podemos nos relacionar - felicidade, tristeza, sofrimento.

JOÃO GUILHERME PEIXOTO - Como você observa/analisa as mudanças nas cadeias de produção, edição e circulação de conteúdo na atividade foto-jornalística? Você acredita que isso traz que tipo de relações para a profissão?

JOÃO GUILHERME PEIXOTO - How do you observe/analyze the changes in production chains, publication and circulation of content in the photojournalistic activity? Do you believe that this brings what kind of relationship to the profession?

SM - It's critical to produce not only quality, but interesting work. Print magazines and newspapers are dwindling. This is inevitable as the world continues to change. It's not good and it's not bad. We just need to be flexible and poised to adapt to the changing media environment.

SM - É fundamental produzir não só qualidade, mas um trabalho interessante. Revistas e jornais impressos estão diminuindo. Isto é inevitável quando o mundo continua a mudar. Não é bom e não é ruim. Nós apenas precisamos ser flexíveis e prontos para se adaptar ao ambiente em mudança de mídia.

LEONILIA GABRIELA BANDEIRA DE SOUZA - Como perceber a fotografia nesses tempos de impermanência?

LEONILIA GABRIELA BANDEIRA DE SOUZA - How to realize the picture in these times of impermanence?

SM - You can't escape the fact that multimedia has given rise to countless television channels, infinite content on the internet, the inundation of images and information everywhere we turn. What I look for in picture is content; a strong and powerful photograph will always be that. That's what stops me in my tracks and drives me to photograph that subject or event, travel the world looking for a story to tell, a striking face, or a culture to document. 
SM - Você não pode escapar do fato de que a multimídia tem dado origem a inúmeros canais de televisão, conteúdo infinito na Internet, a inundação de imagens e informações por todo lado que viremos. O que eu procuro na foto é o conteúdo; uma fotografia forte e poderosa será sempre isso. Isso é o que me faz parar em minhas trilhas e me impulsiona para fotografar aquele assunto ou acontecimento, viajar pelo mundo à procura de uma história para contar, um rosto marcante, ou uma cultura para documentar.

JULIANA LEITÃO - A partir do tema da minha pesquisa, que são os Prêmios de Fotojornalismo, gostaria de saber se você, como fotógrafo premiado, teria resposta para duas perguntas que Galard faz em Beleza Exorbitante sobre algumas imagens memoráveis, trazendo-as para os Prêmios de Fotojornalismo que premia, principalmente, guerras, conflitos e desastres da natureza:

1) Será que essas imagens são difíceis ou impossíveis, necessárias ou ignóbeis, inadmissíveis ou imperativas?

2) O que é uma foto "bem-sucedida" quando, faz muito tempo, a nitidez não é mais indispensável e a imperfeição não é depreciatória?

JULIANA LEITÃO - From the theme of my research, that is about Photojournalism Awards, I wonder if you, as award-winning photographer, could answer two questions of Galard in Exorbitant Beauty about some memorable pictures, bringing them to the Photojournalism Awards that rewards, mainly, wars, conflicts and disasters of nature:

1) Do these images are difficult or impossible, necessary or ignoble, inadmissible or mandatory?

2) What is a "successful" photo when, long ago, the sharpness is no longer necessary and imperfection is not detractive?

SM 1) - I like celebrating people, places and culture through my photography. I also like to tell stories about my subjects through my photographs - especially those I have taken in areas of conflict; and I think this is an important aspect of photojournalism - to expose to the world the truth of what is happening.

SM 1) - Eu gosto de celebrar as pessoas, lugares e cultura através da minha fotografia. Eu também gosto de contar histórias sobre os meus temas através das minhas fotografias - especialmente aqueles fotografados em áreas de conflito, e eu acho que isso é um aspecto importante do fotojornalismo - expor ao mundo a verdade sobre o que está acontecendo.

SM 2) - That varies from picture to picture. Certain technical details might distract from the subject of one image but then enhance another. I think the definition of a successful photograph is one that stays with you, one that's impossible to forget. It's why 
I admire the photographs of Henri Cartier-Bresson. His ability to capture emotion and personality doesn't change because a few years difference. Some of the most celebrated photographs in history are technically "poor".

SM 2) Isto varia de imagem para imagem. Certos detalhes técnicos podem distrair do assunto de uma imagem, mas, em seguida, iluminar um outro. Eu acho que a definição de uma fotografia de sucesso é aquela que fica com você, aquela que é impossível de esquecer. É por isso que eu admiro as fotografias de Henri Cartier-Bresson. Sua habilidade de capturar a emoção e personalidade não muda por causa de alguns anos de diferença. Algumas das fotografias mais célebres da história são tecnicamente "pobres".

MARCOS BUCCINI - Em termos culturais, o que você busca em suas imagens? E como gerar belas imagens de situações de pobreza, guerra e sofrimento?

MARCOS BUCCINI - In cultural terms, what do you seek in your images? And how to generate beautiful images of poverty, war and suffering?

SM - I'm not sure I'm really looking for beauty. I might be looking for something, but I'm not sure that's the word that would define what I'm trying to portray or show, or what point I'm trying to make about what it is that I'm photographing. There may be a certain haunting beauty about some of those pictures, but it wasn't my intention to make it look this way or that way, I was simply documenting what was happening in front of me. Take Dorothea Lange's Migrant Mother. Her look is striking and powerful, but I am not sure I would characterize it as beautiful.

SM - Não tenho certeza se realmente estou procurando pela beleza. Eu certamente estou à procura de algo, mas não tenho certeza se essa é a palavra que define o que estou tentando retratar ou mostrar, ou qual ponto estou tentando tratar sobre o que estou fotografando. Pode haver uma certa beleza assombrosa sobre algumas dessas fotos, mas não era a minha intenção fazer com que pareça desta ou daquela maneira, eu estava simplesmente documentando o que estava acontecendo na minha frente. Tome Mãe Migrante de Dorothea Lange. Seu olhar é impressionante e poderoso, mas não estou certo de que eu poderia caracterizá-lo como bonito.

PATRICIA TENÓRIO - Ao se preparar para uma fotografia, existe alguma história em mente? O quão eloquente são suas fotografias - me referindo à sua série de imagens "A Eloquência do Olhar"? Você procura saber da vida dos seus "retratados", ou deixa livre a fantasia para a criação de uma história, a partir do enquadramento, da luz, das vestes, das cores? O quão de literário você enxerga no ato fotográfico de uma maneira geral e, em particular, no seu ato fotográfico? 
PATRICIA TENÓRIO - When preparing yourself for a photograph, there is a story in mind? How eloquent are your photographs - referring to your series of images "Eloquence of the Eye"? Do you demand to know the lives of your "portraits", or do you let free the fantasy to create a story, from the frame, the light, the clothes, the colors? How do you see the literary in the photographic act in general and, in particular, in your photographic act?

SM - I prefer seeing how things unfold naturally, so I'll seldom have a plan. My photography is about documenting a truth. One of the many things that fascinates me about India and its culture are those vibrant colors and rich culture and history. My photographs are the pursuit of something honest, truthful, and as ethical a manner as possible, unencumbered by any outside preferences or opinions. I think that's what makes the image powerful and catches people's eyes.

SM - Prefiro ver como as coisas se desenrolam naturalmente, então raramente vou ter um plano. Minha fotografia é sobre documentar uma verdade. Uma das muitas coisas que me fascina sobre a Índia e sua cultura são as cores vibrantes e rica cultura e história. Minhas fotografias são a busca de algo honesto, verdadeiro e tão ético como uma forma quanto possível, livre de quaisquer preferências ou opiniões externas. Acho que isso é o que faz a imagem poderosa e captura os olhares das pessoas.

RAFAEL DIAS - Sua relação com a fotografia parece ser de afeto, de um sentimento direcionado não só a rosto de pessoas mas a objetos também. Para você, a imagem é o registro de um olhar pessoal e intransferível ou de uma relação criadora que se põe entre você e o elemento fotografado?

RAFAEL DIAS - Your relation with image and photography seems to be related to a kind of affection, a feeling that you put a light not only upon someone's face but upon objects as well. Do you think your work grasps your own private look or something new that emerges in this contact between you and the other?

SM - I think that each photograph needs to stand on its own, and tell a story by itself. Part of that is the context, objects and culture surrounding the subject. Its part of what makes them who they are, part of what reveals who they are.

SM - Acho que cada fotografia deve permanecer por conta própria, e contar uma história por si só. Parte disto é o contexto, objetos e cultura em torno do assunto. A parte do que os torna quem eles são, parte do que revela quem eles são.

* Steve McCurry has been a one of the most iconic voices in contemporary photography for more than 30 years, with scores of magazine and book covers, over a dozen 
books, and countless exhibitions around the world to his name.

Born in a suburb of Philadelphia, Pennsylvania; McCurry studied film at Pennsylvania State University, before going on to work for a local newspaper. After several years of freelance work, McCurry made his first of what would become many trips to India. Traveling with little more than a bag of clothes and another of film, he made his way across the subcontinent, exploring the country with his camera.

* Extracted from www.stevemccurry.com

* Steve McCurry tem sido uma das vozes mais emblemáticas da fotografia contemporânea por mais de 30 anos, com dezenas de revistas e capas de livros, mais de uma dúzia de livros e inúmeras exposições ao redor do mundo com o seu nome.

Nascido em um subúrbio da Filadélfia, Pensilvânia; McCurry estudou cinema na Universidade Estadual da Pensilvânia, antes de ir trabalhar para um jornal local. Depois de vários anos de trabalho freelance, McCurry fez a primeira do que viria a tornar-se inúmeras viagens para a Índia. Viajando com pouco mais do que um saco de roupas e outra de filme, ele fez o seu caminho em todo o subcontinente, explorando o país com sua câmera.

* Extraído de www.stevemccurry.com 